\title{
The evolution of the nosology of osteogenesis imperfecta
}

\author{
Manogari Chetty $^{1,3}$ (i) | Imaan Amina Roomaney ${ }^{1,3}$ (i) | Peter Beighton ${ }^{1,2,3}$
}

\author{
${ }^{1}$ Faculty of Dentistry, University of the \\ Western Cape, Cape Town, South Africa \\ ${ }^{2}$ Division of Human Genetics, Faculty of \\ Health Sciences, University of Cape Town, \\ Cape Town, South Africa \\ ${ }^{3}$ University of the Western Cape/University of \\ Cape Town Combined Dental Genetics Clinic, \\ Red Cross Childrens' Hospital, Cape Town, \\ South Africa

\section{Correspondence} \\ Prof Manogari Chetty, Faculty of Dentistry, \\ University of the Western Cape, Private Bag \\ X1, Tygerberg 7505, Cape Town, South Africa. \\ Email:drmchetty@mweb.co.za
}

\begin{abstract}
Osteogenesis imperfecta (OI) is a relatively common genetic skeletal disorder with an estimated frequency of 1 in 20000 worldwide. The manifestations are diverse and although individually rare, the several different forms contribute to the production of a significant number of affected individuals with considerable morbidity and mortality. During the last decade, there have been extensive molecular investigations into the etiology of $\mathrm{Ol}$ and these advances have direct relevance to the medical management of the disorder, and the purpose of this review is to document the history and evolution of the nosology of OI. The current nosology, based on molecular concepts, which are crucial in the identification of genotype-phenotype correlations in persons with OI, is also outlined. The successive revisions of the nosology and classification of OI have highlighted the importance of the nomenclature of the condition in order for it to be recognized by clinicians, scientists and patient advocacy groups. In this way, improved counseling of patients and individualized, tailored therapeutic approaches based on the underlying pathophysiology of the individual's type of OI have been facilitated.

KEYWORDS

genetic, nosology, osteogenesis imperfecta, thin bones
\end{abstract}

\section{1 | INTRODUCTION}

Osteogenesis imperfecta $(\mathrm{OI})$ is a relatively common genetic skeletal disorder with an estimated frequency of 1 in 20000 worldwide. ${ }^{1}$ The manifestations are diverse and although individually rare, the several different forms contribute to the production of a significant number of affected individuals with considerable morbidity and mortality.

The historical accumulation of knowledge concerning OI has been chronicled in successive editions of Victor McKusick's book "Heritable Disorders of Connective Tissue". ${ }^{2}$ In the mid-nineteenth century, Lobstein (Figure 1) documented the adult form of Ol while Vrolik (Figure 1) described the lethal infantile type. At the beginning of the 20th century, Looser of Heidelberg introduced the terms "OI tarda" and "Ol congenita". These designations have remained in use in clinical medicine. ${ }^{3}$

With the introduction of clinical genetics in the 1960s, the autosomal dominant (AD) mode of inheritance of the common adult form, OI-tarda became well established. In OI-congenita, the infantile form of OI, the consistent normality of the parents and the occasional recurrence in siblings were suggestive of autosomal recessive (AR) inheritance. ${ }^{3}$

In recent years, the classification of $\mathrm{Ol}$ has been the subject of extensive discussion and the nosology has evolved with advances in molecular investigations resulting in the delineation of 20 forms of OI. This classification embodied the molecular heterogeneity of the disorder, but the resultant complexity subsequently resulted in confusion in clinical practice. For this reason, the initial phenotypically based Sillence classification has also been maintained. ${ }^{4}$ It is significant that in 1979 , Sillence et al anticipated the future discovery of considerable heterogeneity. ${ }^{4}$ It is evident that both these approaches are different yet mutually beneficial for the optimal management of persons with OI.

The complexity of the current categorization became apparent during a study undertaken in South Africa which documented the oral and craniofacial manifestations in 64 Black South African persons with a confirmed diagnosis of osteogenesis imperfecta type III (OI III), based on the phenotypic manifestations of the disorder. ${ }^{5}$ Subsequent molecular investigations resulted in 23 of these individuals being 
FIGURE 1 Jean Frederick Lobstein 1777 to 1835 and Willem Vrolik 1801 to 1863. Google: https://commons. wikimedia.org (July 2015)
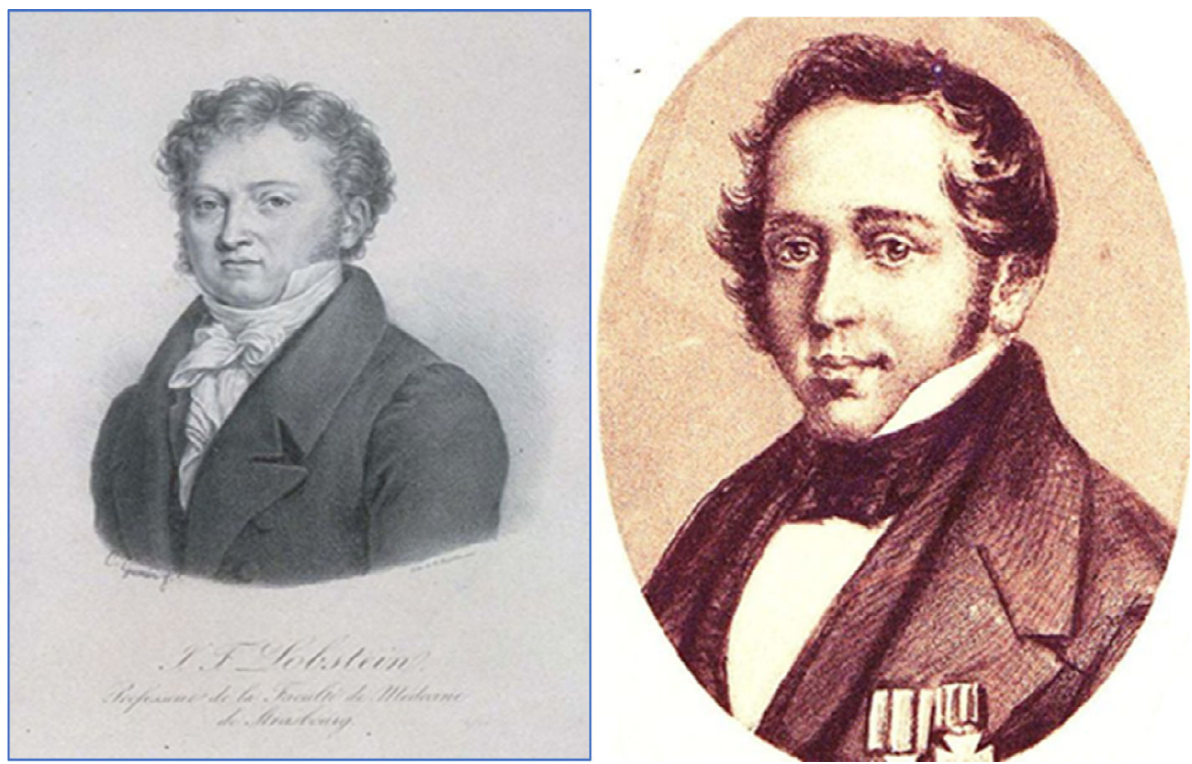

further delineated as having the OI XI genotype due to homozygous mutations in FKBP10. ${ }^{6}$

During the last decade, extensive molecular investigations into the etiology of OI have been undertaken and it has emerged that the molecular determinants are complex. These advances have direct relevance to the medical management of the disorder and the purpose of this review is to document the history and evolution of the nosology of Ol. The current nosology, based on molecular concepts, which are crucial in the identification of genotype-phenotype correlations in persons with $\mathrm{OI}$, is also outlined.

\section{METHODS}

An electronic literature search was conducted using PubMedMEDLINE, EBSCOhost, World of Science and Google Scholar. We searched these databases for terms relating to the nosology of OI, including "Osteogenesis Imperfecta", "nosology OR nomenclature OR classification". The authors used expanded terms and MeSH terms, where possible, to broaden our search. We then hand searched the reference lists of relevant studies to find related studies.

Of the 600 titles obtained from our literature search, 179 were found to be relevant and evaluated for inclusion. We extracted useful information and collated it to be included in this review. Results were organized according to chronological order using dated subheadings for clarity and to reflect the rapid expansion of knowledge over the last decade.

\section{\begin{tabular}{l|l}
3 & RESULTS
\end{tabular}}

In 1788, Olaus Jacob Elkman described a family with a condition termed "Osteomalaciae Sistens" in a fragile boned family, which had various features associated with $\mathrm{OI}$. In the years to follow over
20 different synonyms or eponyms had been used to describe OI. The phenotypic heterogeneity contributed to a failure to group these conditions under a single umbrella-term. ${ }^{7}$

For the sake of chronological organization and clarity, dated subheadings have been employed. The increasing pace of the expansion of knowledge is reflected in the presentation of the years and decades.

\section{\begin{tabular}{l|l}
3.1 & $1970 ' s$
\end{tabular}}

A group of experts from the field of genetics, pediatrics and pediatric radiology at a meeting of the European Society of Paediatric Radiology, gathered in 1970, in Paris and developed the first "Nomenclature of Constitutional Diseases of Bone". This document was referred to as The Paris Nomenclature, ${ }^{8}$ and it was widely accepted and published. The purpose of this nomenclature was to standardize the terminology used to designate the different entities, which comprise the group of constitutional or intrinsic diseases of bone. Thereafter, the Paris Nomenclature was regularly updated with revision meetings held in 1977, 1983, 1992, 1997, 2001, 2005, 2010, 2015 and 2019.

The impetus to the understanding of OI was afforded by Sillence et $\mathrm{al}^{4}(1979)$ when subdivision into four main types was proposed. This numerical classification was based upon an analysis of clinical manifestations and the putative mode of inheritance (Table 1).

The Sillence classification does not reflect the true heterogeneity of the syndrome, but it remains useful in terms of genetic counseling and for the prediction of the clinical evolution of the disorder. In this way, decisions on therapeutic measures are facilitated and optimal management can be provided for the patients. Persons who receive details regarding testing, treatment and available choices are thereby, empowered to make appropriate decisions regarding pregnancy and their child's health. 
TAB LE 1 Classification of osteogenesis imperfecta ${ }^{4}$

\begin{tabular}{|lll} 
Type & Clinical features & MOI \\
\hline I & Blue sclera, moderate bone fragility & AD \\
II & Lethal in the perinatal period & AR \\
III & $\begin{array}{l}\text { White sclera, severe with progressive } \\
\text { deformity }\end{array}$ & AR \\
IV & White sclera, variable bone fragility & AD \\
\hline
\end{tabular}

Abbreviations: AD, autosomal dominant; $A R$, autosomal recessive; $M O I$, mode of inheritance.

\section{2 | 1980's}

By the 1980s, discoveries in collagen biochemistry and later in molecular biology conclusively revealed that the Ol-congenita phenotype usually resulted from new dominant mutations. ${ }^{9,10}$ At that time the occasional occurrence in siblings was explained on the basis of gonadal mosaicism. Most instances of $A D \mathrm{OI}$ are caused by mutations in the COL1A1 and COL1A2 genes. These genes are located on chromosome 17 and 7, respectively, and encode the polypeptide chains of type I collagen.

A multiexon deletion in a collagen gene, COL1A1 was discovered in $1983^{11}$ and in 1986 , a heterozygous single nucleotide substitution in COL1A1 was identified as the cause of the form of Ol which was lethal in infants and young children.

\section{\begin{tabular}{l|l}
3.3 & $1990 ' s$
\end{tabular}}

The second official revision of the Paris Nomenclature took place in 1991 at a meeting of the International Working Group on Bone Dysplasias in Bad Honnef. ${ }^{12}$ At this time, the classification of OI was orientated on radiographic and morphological criteria and encompassed the Sillence classification of four main types.

The third official revision of the 1972 Paris Nomenclature of Constitutional Disorders of Bone took place in 1997 in Los Angeles. In this version of the revised nomenclature, the groups of disorders were arranged based on etiopathogenetic information concerning the gene and/or the protein defect. Thirty-two groups of conditions were listed and OI was included in group 23 which was designated Dysplasias with Decreased Bone Density. The Sillence classification of the four main types was maintained and mutations in the COL1A1 and COL1A2 genes were documented.

Following the establishment of the International Society of Skeletal Dysplasia (ISDS) in 1999, the revisions were prepared by a group of experts within the ISDS and the term nomenclature was replaced with "nosology".

\section{4 | 2000 to 2020}

The next official revision took place in 2001 in Oxford and was published in 2002.This version included 33 groups of disorders with OI being placed in group 24. Two new subtypes of Ol were included, namely, Type $\mathrm{V}$, which was characterized by the presence of dislocated radial heads and hyperplastic callus formation and Type VI, diagnosed on the bone histology. ${ }^{13}$

An expanded Sillence classification was published in $2004 .{ }^{14}$ These authors added OI types $\mathrm{V}$ to $\mathrm{VII}$, in which the underlying genetic defects were initially unknown. Thereafter, following comprehensive radiographic, bone morphologic and molecular genetic analyses, the establishment of an expanded classification was promulgated. Details are given in Table $2{ }^{15}$

In August 2009, in Boston, the Nosology Committee of the International Skeletal Dysplasia Society identified 456 genetic conditions and placed them into 40 groups, which were defined by molecular, biochemical and/or radiographic criteria. ${ }^{16} \mathrm{OI}$ was given special attention at this meeting and was placed in group 25 (Table 3).

Confusion was engendered by the aetiological complexity of the different forms of Ol. Accordingly, the Nosology Committee suggested that the Sillence classification, which defined and classified Ol according to clinical characteristics and inheritance pattern and not molecular findings should be retained in clinical practice. ${ }^{16}$ In this "Working Nosology" Arabic numerals are used instead of Roman numerals (Table 4).In the tables below the grouping is compared with the historic numerical nomenclature but note that the International Nosology committee recommends Arabic numerals rather than Roman numerals.

In 2012, the molecular abnormality was identified in the rare AD OI type 5 in which IFITM5 encodes Interferon-induced transmembrane protein $5 .{ }^{17} \mathrm{~A}$ further $10 \%$ of AR OI has been shown to be caused by a growing list of mutant genes. These include LEPRE1, PPIB, PLOD2, FKBP10, SERPINH1, SERPINF1, BMP1, SP7, CRTAP and TMEM38B. ${ }^{18-24}$ Mutations in WNT1, which encodes a signaling molecule in osteoblast differentiation and proliferation, have also been identified. ${ }^{25} \mathrm{~A}$ homozygous deletion of CREB3L1 was identified in a family with the progressively deforming OI phenotype has also been documented. $^{26}$

With the discovery of each new genetic determinant and following further revisions of the nomenclature, the Sillence classification was expanded to include documented types of OI I to OI XV. ${ }^{27}$ The categories OI I - OI IV were defined according to the radiological and clinical presentation of the disorder, whereas OI $\mathrm{V}$ to $\mathrm{OI} X \mathrm{~V}$ were established on the basis of the molecular findings. It is relevant, however, that there is considerable overlap in the clinical presentation of OI I to OI IV and OI V to OI XV. ${ }^{28,29}$

The ninth edition of the Nosology published in 2015 lists 436 disorders in 42 groups and records 364 determinant genes. ${ }^{30}$ OI remains in group 25 and the phenotypically based Sillence classification is still maintained. OI type 5 has been included since it is radiologically distinct from other forms of OI. The nomenclature used with regard to Ol is that which was recommended in 2011. This data are given in Table 4.

The number of genes documented in Ol type 1 and Ol type 2 remains the same as those recorded in 2011 . Conversely, the number of genes involved in Ol type 3 has increased from 7 in 2011 
TABLE 2 Expanded classification of osteogenesis imperfecta ${ }^{15}$

\begin{tabular}{|c|c|c|c|c|c|c|c|c|}
\hline Type & MOI & Severity & Fractures & BD & Stature & DI & Sclerae & Hearing loss \\
\hline I & AD & Mild & Few to 100 's +/- & Common & $\begin{array}{l}\text { Normal or } \\
\text { slightly short }\end{array}$ & $+/-$ & Blue & $\begin{array}{l}\text { Present in } \\
+/-50 \%\end{array}$ \\
\hline II & AD & $\begin{array}{c}\text { Perinatal } \\
\text { lethal }\end{array}$ & $\begin{array}{l}\text { Multiple fractures of ribs, minimal calvarial } \\
\text { mineralization platyspondyly, marked } \\
\text { compression of long bones }\end{array}$ & Severe & $\begin{array}{l}\text { Severely short } \\
\text { stature }\end{array}$ & + & Dark blue & - \\
\hline III & AR & Severe & $\begin{array}{l}\text { Thin ribs, platyspondyly, thin fragile bones } \\
\text { with many fractures, "popcorn" } \\
\text { epiphyses common }\end{array}$ & $\begin{array}{l}\text { Moderate to } \\
\text { severe }\end{array}$ & Very short & + & Blue & Often \\
\hline IV & $A D$ & $\begin{array}{c}\text { Moderate } \\
\text { to mild }\end{array}$ & Multiple & Mild to moderate & $\begin{array}{l}\text { Variably short } \\
\text { stature }\end{array}$ & $+/-$ & $\begin{array}{l}\text { Normal to } \\
\text { gray }\end{array}$ & Some \\
\hline V & $A D$ & Moderate & Multiple with hypertrophic callous & Moderate & Variable & - & $\mathrm{N}$ & No \\
\hline VI & AR & Moderate & Multiple & $\begin{array}{l}\text { Rhizomelic } \\
\text { shortening }\end{array}$ & $\begin{array}{l}\text { Mild short } \\
\text { stature }\end{array}$ & - & $\mathrm{N}$ & No \\
\hline VII & AR & Moderate & Multiple & Yes & $\begin{array}{c}\text { Mild short } \\
\text { stature }\end{array}$ & - & $N$ & No \\
\hline
\end{tabular}

Abbreviations: $A D$, autosomal dominant; $A R$, autosomal recessive; $B D$, bone deformity; $\mathrm{DI}$, dentinogenesis imperfecta; $\mathrm{MOI}$, mode of inheritance.

TAB LE 3 Category 25: osteogenesis imperfecta and decreased bone density group ${ }^{16}$ (modified by the author to only include OI and related conditions)

\begin{tabular}{|c|c|c|c|c|c|}
\hline Name of disorder & MOI & MIM No. & Locus & Gene & Protein \\
\hline \multirow[t]{2}{*}{ OI, non-deforming (OI 1) } & \multirow[t]{2}{*}{$A D$} & \multirow[t]{2}{*}{166200} & & \multirow[t]{2}{*}{ COL1A1, COL1A2 } & COL1A1: collagen 1 alpha 1 chain \\
\hline & & & & & COL1A2: collagen 1 alpha 2 chain \\
\hline OI, perinatal lethal form (OI 2) & $A D, A R$ & 166210 & & $\begin{array}{l}\text { COL1A1, COL1A2, CRTAP, } \\
\text { LEPRE1, PPIP }\end{array}$ & $\begin{array}{l}\text { LEPRE1: leucine proline enriched } \\
\text { proteoglycan (leprecan) }\end{array}$ \\
\hline \multirow{2}{*}{$\begin{array}{l}\text { OI, progressively } \\
\text { deforming type (OI 3) }\end{array}$} & \multirow[t]{2}{*}{$A D, A R$} & \multirow[t]{2}{*}{259420} & & \multirow{2}{*}{$\begin{array}{l}\text { COL1A1, COL1A2, CRTAP, } \\
\text { LEPRE1, PPIP, FKBP10, } \\
\text { SERPINH1 }\end{array}$} & FKBP10: FK506 binding protein 10 \\
\hline & & & & & $\begin{array}{l}\text { SERPINH1: serpin peptidase inhibitor, } \\
\text { clade } \mathrm{H} \text {, member } 1\end{array}$ \\
\hline OI, moderate form (OI 4) & $A D, A R$ & 166220 & & $\begin{array}{l}\text { COL1A1, COL1A2, CRTAP, } \\
\text { FKBP10, SP7 }\end{array}$ & SP7: SP7 transcription factor (osterix) \\
\hline \multicolumn{6}{|l|}{ OI: other types } \\
\hline Bruck syndrome type I & $A R$ & 259450 & $17 q 21$ & FKBP10 & FK506 binding protein 10 \\
\hline Bruck syndrome type II & $A R$ & 609220 & $3 q 23-24$ & PLOD2 & Procollagen lysyl hydroxylase 2 \\
\hline Osteoporosis-pseudoglioma syndrome & AR & 259770 & $11 q 12-13$ & LRP5 & LDL-receptor related protein 5 \\
\hline
\end{tabular}

Abbreviations: AD, autosomal dominant; AR, autosomal recessive; $\mathrm{MOI}$, mode of inheritance; OI, osteogenesis imperfecta.

to 15 , while in Ol type 4 the number of listed genes increased from 5 to 8 . The gene and the associated protein in Ol type 5 were identified $^{17}$ (Table 5).

Bruck syndrome (BS) type 1, BS type 2 and osteoporosispseudoglioma syndrome are currently listed as autonomous disorders in group $25^{30}$ and not as "Ol, Other types" as previously designated. ${ }^{16}$

The 2015 Nosology Committee concluded that OI is a classic skeletal disorder whereby molecular diagnosis depends on next-generation sequencing, although the prognosis is centered on phenotypic observations.

By this stage, it was evident that there was a detailed understanding of the molecular events necessary for collagen synthesis (COL1A1 and COL1A2), post-translational processing/modification (CRTAP, LEPRRE1, PPIB and TMEM38B), folding and crosslinking (SERPINH1, FKBP10 and PLOD2). Equally, many of the key genes/proteins involved in the pathogenesis of $\mathrm{Ol}$ had been elucidated. It was also 
TAB LE 4 Recommended nomenclature of osteogenesis imperfecta (OI) syndromes in order of severity (Nosology Committee of the International Skeletal Dysplasia Society (ISDS) ${ }^{16}$

\begin{tabular}{|c|c|}
\hline $\begin{array}{l}\text { Name of syndrome (recommended } \\
\text { nomenclature of OI syndromes) }\end{array}$ & $\begin{array}{l}\text { Equivalent } \\
\text { numerical types }\end{array}$ \\
\hline $\begin{array}{l}\text { Classic non-deforming OI with blue sclerae (OI } \\
\text { type 1) }\end{array}$ & 1 \\
\hline $\begin{array}{l}\text { Common variable OI with normal sclerae (OI type } \\
\text { 4) }\end{array}$ & IV \\
\hline $\begin{array}{l}\text { Ol with calcification in interosseous membranes } \\
\text { (OI type } 5)\end{array}$ & V \\
\hline $\begin{array}{l}\text { Progressive deforming OI with normal sclerae (OI } \\
\text { type 3) }\end{array}$ & III \\
\hline Perinatally lethal OI (OI type 2) & ॥ \\
\hline
\end{tabular}

apparent that other non-collagen genes, notably CREB3L1 and SP7, have roles in osteoblast differentiation.

In order to account for the rapidly growing list of new genes associated with OI, Forlino and Marini ${ }^{31}$ proposed a functional metabolic classification scheme. This incorporated both clinical and genetic information for subtyping the condition on the basis of the altered intracellular or extracellular metabolic pathways (Table 6).

In the latest edition of the Nosology (2019), the pathogenic variants have been listed for $92 \%$ (425/461) of the disorders, which were included. ${ }^{32}$ Formerly, the percentage of disorders in which the causal gene was identified was $58 \%(215 / 372)$ in the 2006 revision, ${ }^{33} 69 \%$ (316/456) in the 2010 revision, ${ }^{16}$ and $88 \%(385 / 436)$ in the 2015 revision. ${ }^{30}$ In distinction to preceding revisions, the protein is not listed, since this can be determined from the gene. The reference list of clinically recognized entities and their causal genes presented in this 2019 edition of the Nosology may assist clinicians to attain an accurate diagnosis for their patients and help enhance research in skeletal biology.

Ol is included in the "Osteogenesis Imperfecta and decreased bone density group" category 25 (Table 7). Although the phenotypically based Sillence classification is maintained, the classification of OI has now expanded up to OI type XX, with the latest addition, mutations in MESD resulting in a progressive deforming OI phenotype.

The PLOD2 and SEC24D genes have been removed as pathological variants involved in OI 3, although PLOD2 remains listed as a pathological variant in BS type 2. Two new genes, SPARC ${ }^{34}$ and TENT5A ${ }^{35}$ have been identified and included as causal genes in OI 3 .

Clinical entities, osteoporosis $X$-linked form and osteoporosis AD form are also included in group $25 .{ }^{32}$ In addition to the clinical entity associated with the PLS3 gene, a recently recognized gene, MBTPS2 which is now diagnosed as OI type XIX, is also implicated in the pathogenesis of X-linked Osteoporosis. ${ }^{36}$ The WNT1 and LRP5 genes are listed as being involved in the pathogenesis of OI type $\mathrm{XV}$ and the $\mathrm{X}$ linked form of AD osteoporosis, respectively. ${ }^{32}$ The clinical entity, OI with calvarial doughnut lesions, has been found to result from mutations in SGMS2. ${ }^{37}$ A further rare type of familial osteoporosis previously known as OI with jaw lesions, Levin type, was confirmed to result from mutations in ANO5. ${ }^{38}$

\section{4 | DISCUSSION}

The original classification, which was promulgated by Sillence in 1979 was comprised of four subtypes determined by severity, phenotype and radiological findings. Thereafter, the evolution in molecular genetics resulted in the discovery of several additional causative genes for Ol. The identification of these novel genes has greatly enhanced the

TAB LE 5 Category 25: osteogenesis imperfecta and decreased bone density group, ${ }^{30}$ (modified by the author to only include Ol and related conditions)

\begin{tabular}{|c|c|c|c|c|}
\hline Name of disorder & MOI & MIM No. & Gene & Protein \\
\hline \multirow[t]{9}{*}{ Ol type 3} & \multirow[t]{9}{*}{$A D, A R$} & \multirow[t]{9}{*}{259420} & $\begin{array}{l}\text { COL1A1, COL1A2, CRTAP, } \\
\text { LEPRE1, PPIP, FKBP10, } \\
\text { SERPINH1 }\end{array}$ & Refer to OI type 3 (Table 3 ) \\
\hline & & & \multirow{8}{*}{$\begin{array}{c}\text { aBMP1, PLOD2, SERPINF1, } \\
\text { SP7, WNT1, TMEM38B, } \\
\text { CREB3L1, SEC24D }\end{array}$} & BMP: bone morphogenetic protein 1 \\
\hline & & & & PLOD: procollagen lysyl hydroxylase 2 \\
\hline & & & & SERPINF1: serpin peptidase inhibitor, clade F, member 1 \\
\hline & & & & SP7: SP7 transcription factor (osterix) \\
\hline & & & & $\begin{array}{l}\text { WNT1: wingless-type MMTV integration site family, member } \\
1\end{array}$ \\
\hline & & & & TMEM38B: transmembrane protein 38B \\
\hline & & & & CREB3L1: OASIS \\
\hline & & & & SEC24D: SEC24-related gene family, member D \\
\hline \multirow[t]{2}{*}{ OI type 4} & \multirow[t]{2}{*}{$A D, A R$} & \multirow[t]{2}{*}{166220} & $\begin{array}{l}\text { COL1A1, COL1A2, CRTAP, } \\
\text { FKBP10, SP7 }\end{array}$ & Refer to OI type 3 above \\
\hline & & & ${ }^{a}$ WNT1, SERPINF1, PPIB & PPIP: peptidylprolyl isomeraseB (cyclophilin B) \\
\hline Ol type 5 & $A D$ & 610967 & aIFITM5 & Interferon induced transmembrane protein 5 \\
\hline
\end{tabular}

Abbreviations: AD, autosomal dominant; $A R$, autosomal recessive; $\mathrm{MOI}$, mode of inheritance; OI, osteogenesis imperfecta.

${ }^{\text {a }}$ The genes are the latest additions to the 2015 nosology list. 
understanding of the cellular and biological pathways involved in OI. However, the rapid pace of these discoveries has resulted in the publication of multiple classifications, which often times proves challenging for the clinician to remain abreast of and for the patient to understand.

This review was conducted in order to document the history and evolution of the nosology of OI from the four simple types described in 1979 to the heterogenous 29 types described in 2019. Undoubtedly, with advances in molecular and biochemical techniques, this classification will continue to evolve, and our understanding of the genotype-phenotype correlations will continue to expand. It is, however, important that researchers and clinicians are familiar with the historic nomenclature to better understand and utilize the wealth of existing literature, which is available.

It is well known that disharmony in osteoblast and osteoclast activity can result in irregularities in bone density. The understanding of the molecular basis for bone development and remodeling has improved significantly in recent years. Several of the identified disease-causing genes in Ol can be classified into one of three major signaling pathways based on their function. These are collagen I biosynthesis, WNT signaling and TGF $\beta$ signaling. A majority of the recently identified pathogenic variations encode for proteins involved in the post-translational modification of collagen and genetic defects in osteoblast development. A few disease-causing genes that function in bone formation is still unclear and independent of the previously mentioned signaling pathways.

Collagen, in particular collagen type $\mathrm{I}$, is the most abundant and important organic component of the extracellular matrix which provides bone with flexibility and strength. Hence, a mutation in one of the genes responsible for collagen type 1 synthesis and assembly can be a causative factor in Ol. Approximately $90 \%$ of the $A D$ forms of OI which result from mutations in COL1A1 and COL1A2 have been identified (Figure 2). ${ }^{39}$

The remaining $10 \%$ of the AR types of Ol result from mutations in CRTAP, LEPREI1, PLOD2, CREB3L1, PPIB, SERPINH1, SERPINF1, FKBP10, TMEM38B, MBTPS2, SPARC and BMP. These genes are directly or indirectly involved in the collagen type I synthesis and assembly (Figure 3). ${ }^{40}$

Apart from genes involved in collagen 1 biosynthesis, mutations in genes that are involved in other pathways pertinent to bone formation have also been reported. Mutations in WNT1, a ligand of the WNT signaling pathway and mutations in $S p 7$, which encodes osterix,

TAB LE 6 Novel gene subtypes of osteogenesis imperfecta. Adapted from Forlino and Marini (2016) ${ }^{31}$

\begin{tabular}{|c|c|c|c|c|c|c|}
\hline Type & MOI & Gene & Protein & Disease mechanism & Skeletal phenotype & Associated features \\
\hline I & $A D$ & COL1A/2 & Collagen type $1, \alpha 1 / 2$ & $\begin{array}{l}\text { Collagen synthesis/ } \\
\text { processing }\end{array}$ & Mild-moderate & DI, blue sclera, deafness \\
\hline III & $A D$ & & & & Severe & \\
\hline IV & $A D$ & & & & Moderate & DI, basilar invagination \\
\hline VI & $A R$ & SEPINF1 & $\begin{array}{l}\text { Pigment epithelium-derived } \\
\text { factor }\end{array}$ & Mineralization defect & Moderate-severe & $\begin{array}{l}\text { "Fish scale" pattern on iliac } \\
\text { crest biopsies }\end{array}$ \\
\hline VII & $\mathrm{AR}$ & CRTAP & Cartilage-associated protein & Collagen modification & Severe-lethal & Similar to IV, rhizomelia \\
\hline VIII & $A R$ & LEPRE1 & $\begin{array}{l}\text { Leucine proline-enriched } \\
\text { proteoglycan 1/prolyl } \\
\text { 3-hydroxylase } 1\end{array}$ & Collagen modification & Severe-lethal & Platyspondyly, scoliosis \\
\hline$x$ & $\mathrm{AR}$ & SERPINH1 & Serpin peptidase inhibitor & $\begin{array}{l}\text { Chaperone defect collagen } \\
\text { folding }\end{array}$ & Severe & Nephrolithiasis \\
\hline $\mathrm{XI}$ & $A R$ & FKBP10 & FK506 binding protein 65 & $\begin{array}{l}\text { Chaperone defect collagen } \\
\text { folding }\end{array}$ & Moderate-severe & Congenital contractures \\
\hline XII & $\mathrm{AR}$ & SP7 & Transcription factor 7 & Osteoblast development & Moderate & Midface hypoplasia \\
\hline XIII & $A R$ & $B M P 1$ & Bone morphogenic protein 1 & $\begin{array}{l}\text { Collagen synthesis/ } \\
\text { processing }\end{array}$ & Mild-severe & Umbilical hernia \\
\hline XIV & $A R$ & TNEM38B & Transmembrane protein $38 \mathrm{~B}$ & Collagen modification & Severe & \\
\hline$X V$ & $A R$ & WNT1 & Wingless-type member 1 & Osteoblast development & Moderate-severe & Neurological deficits \\
\hline $\mathrm{XVI}$ & $\mathrm{AR}$ & CREB3L1 & $\begin{array}{l}\text { CAMP responsive element } \\
\text { binding }\end{array}$ & Osteoblast development & Severe & \\
\hline
\end{tabular}

Abbreviations: $A D$, autosomal dominant; $A R$, autosomal recessive; $D I$, dentinogenesis imperfecta; $M O I$, mode of inheritance. 
an important regulator of mesenchymal stem cell differentiation have been described. ${ }^{25,41}$ Finally, OI type $\mathrm{V}$ is caused by mutations in the IFITM5 gene of which the function is still largely unknown. ${ }^{42}$ Homozygous mutations in WNT1 cause OI types III and XV. Heterozygous inactivating mutations in WNT1 and heterozygous loss of function mutations in LRP5 are also indicated in juvenile osteoporosis. ${ }^{43}$ Both in vivo and in vitro studies have determined that the TGF $\beta$ signaling pathway can influence bone formation and resorption and is an essential regulator of bone remodeling. ${ }^{44}$

Using exome sequencing, mutations in PLS3 were identified in a family with $x$-linked osteoporosis although the role of PLS3 in bone remodeling is uncertain. Based on the ability of PLS3 to bind actin and the expression of PLS3 in osteocytes, a role in mechano-sensing has been proposed. ${ }^{44}$ Osteocytes induce increased bone formation by suppressing SOST expression as an adaption to mechanical loading. In this way, mutations in PLS3 could explain the osteoporotic phenotype in patients. ${ }^{45}$

Over the years, the diagnosis of OI has been dependent on the correlation of clinical data with analysis of relevant radiographs and biochemical findings. Until recently, molecular genetic confirmation has often been the concluding step in the diagnostic process. However, there is considerable overlap in the clinical presentation caused by the various molecular defects. This implies that the molecular cause cannot be deduced from the clinical presentation of the

TAB LE 7 Category 25: osteogenesis imperfecta and decreased bone Density group, ${ }^{32}$ (modified by the author to only include Ol and related conditions as well as the additional loci recently reported)

\begin{tabular}{|c|c|c|c|c|}
\hline Name of disorder & MOI & OMIM No. & Gene & Molecular diagnosis OMIM \\
\hline Ol type 1 & $A D$ & 166200 & COL1A1, COL1A2 & Ol type I \\
\hline \multirow[t]{3}{*}{ Ol type 2} & $A D$ & 166200 & COL1A1, COL1A2 & Ol type II \\
\hline & $A R$ & 610915 & LEPRE1 & OI type VIII \\
\hline & AR & 259440 & PPIP & OI type IX \\
\hline \multirow[t]{11}{*}{ Ol type 3} & $A D$ & 259240 & COL1A1, COL1A2 & OI type III \\
\hline & $A R$ & 613982 & SERPINF1 & OI type VI \\
\hline & $\mathrm{AR}$ & 610682 & CRTAP & OI type VII \\
\hline & $\mathrm{AR}$ & 610915 & LEPRE1 & OI type VIII \\
\hline & $A R$ & 259440 & PPIB & OI type IX \\
\hline & $A R$ & 112264 & BMP1 & Ol type XIV \\
\hline & $\mathrm{AR} / \mathrm{AD}$ & 615220 & WNT1 & OI type $\mathrm{XV}$ \\
\hline & $A R$ & 616229 & CREB3L1 & Ol type XVI \\
\hline & $A R^{a}$ & $616507^{\mathrm{a}}$ & $S P A R C^{\mathrm{a}}$ & OI type XVII ${ }^{\mathrm{a}}$ \\
\hline & $\mathrm{AR}^{\mathrm{a}}$ & $617952^{\mathrm{a}}$ & TENT5A(FAM24A $)^{a}$ & OI type XVIIII \\
\hline & $\mathrm{AR}^{\mathrm{a}}$ & $607783^{a}$ & $M E S D^{\mathrm{a}}$ & Ol type $X X^{a}$ \\
\hline \multirow[t]{2}{*}{ Ol type 4} & $A D$ & 166220 & COL1A1, COL1A2 & OI type IV \\
\hline & $A D$ & 615220 & WNT1 & OI type XV \\
\hline Osteoporosis $\mathrm{X}$-linked form ${ }^{\mathrm{a}}$ & $X \mathrm{~L}$ & & MBTPS2 & \\
\hline \multirow[t]{2}{*}{ Osteporosis AD form ${ }^{a}$} & $A D$ & 615220 & WNT1 & Ol type XV \\
\hline & $A D$ & & LRP5 & \\
\hline
\end{tabular}

Abbreviations: $A D$, autosomal dominant; $A R$, autosomal recessive; $\mathrm{MOI}$, mode of inheritance; OI, osteogenesis imperfecta.

${ }^{a}$ The genes and clinical conditions are the latest additions to the 2019 nosology list. 

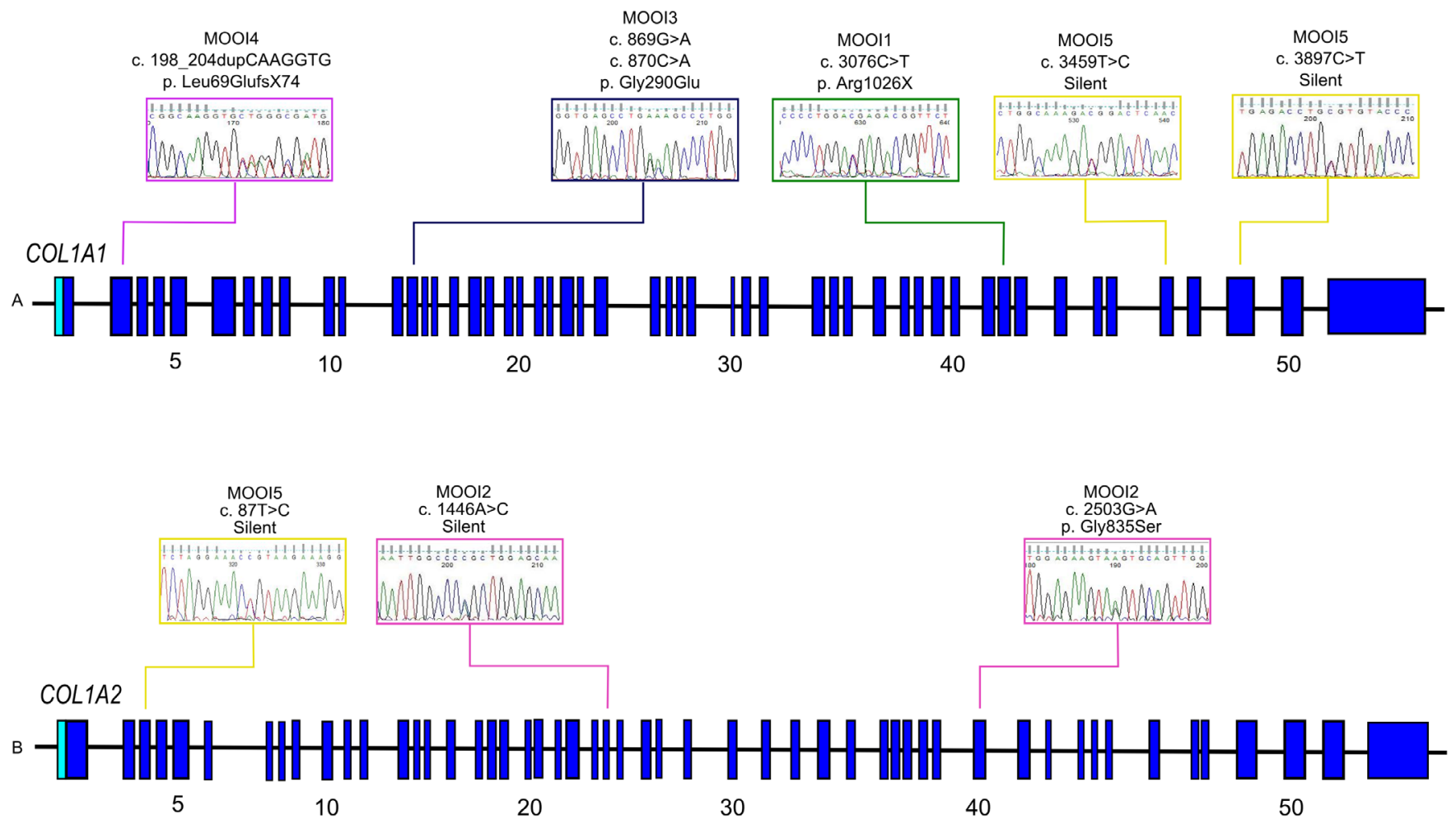

FIGURE 2 Novel mutations are shown in a schematic representation of the COL1A1 and COL1A2 genes in five patients with OI. In COL1A1: one missense mutation (p. Gly290Glu), one nonsense mutation (Arg1026Ter), one out-of-frame insertion mutation (p. Leu69GlufsX74) and two silent mutations. In COL1A2: one missense mutation (p. Gly835Ser) and two silent mutations

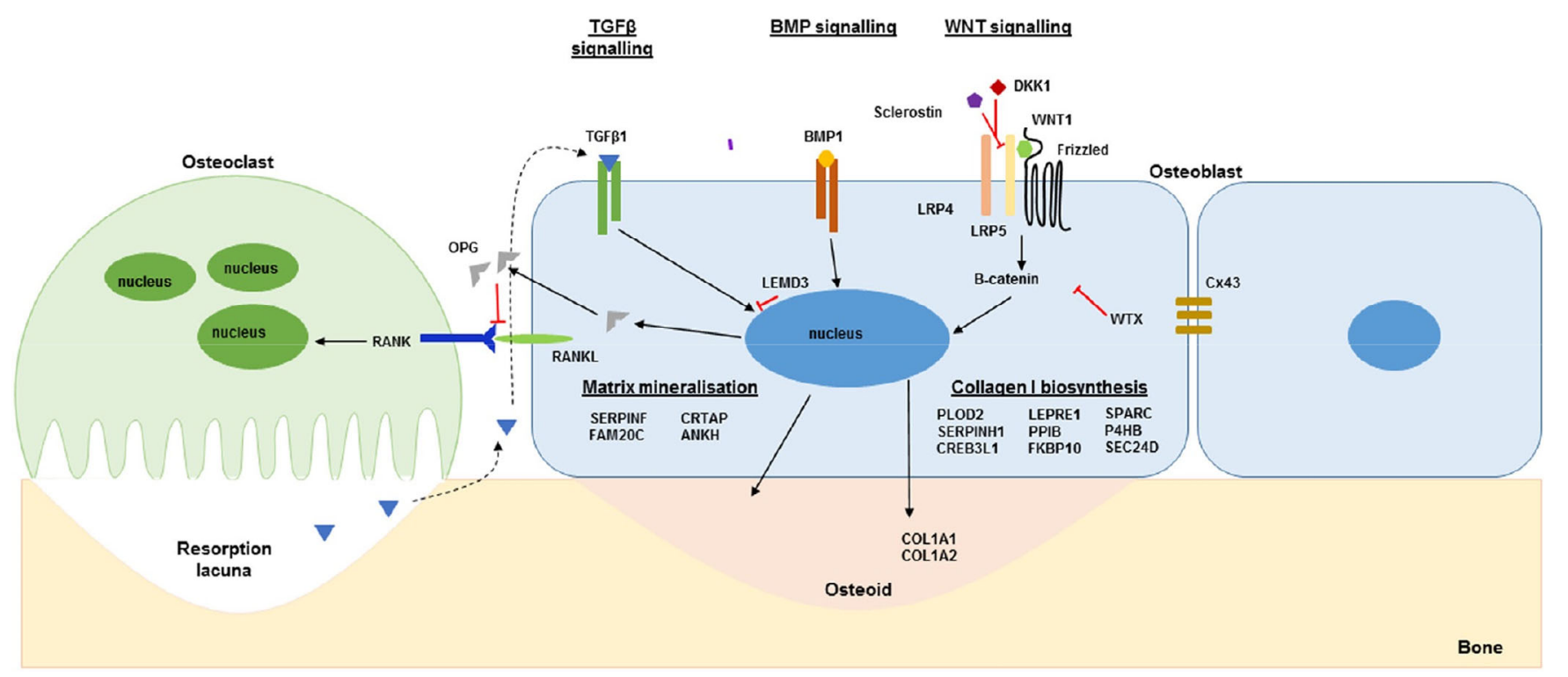

FIGURE 3 A schematic representation of the most important signaling pathways regulating bone remodeling which have been identified through the investigation of monogenic bone disorders such as osteogenesis imperfecta ${ }^{36}$

patient. ${ }^{46}$ A notable exception is the distinctive features of AD IFITMrelated OI. ${ }^{17,47}$ To add to the complexity of attempting to correlate a molecular diagnosis from a clinical picture, the previously established relative frequencies of OI types do not appear to hold true to more recent studies using next-generation sequencing, especially in those from developing countries. ${ }^{48,49} 85 \%$ to $90 \%$ of Ol cases are believed 
to be due to COL1A1 and COL1A2 defects ${ }^{28,50}$ and AD IFITM5 defects are the most prevalent non-collagenous form of OI. ${ }^{51} \mathrm{How}$ ever, studies conducted in China, ${ }^{52}$ Malaysia, ${ }^{53}$ India $^{54}$ and Brazil ${ }^{42}$ found between $49 \%$ and $73 \%$ of $\mathrm{OI}$ are due to COL1A1 and COL1A2 defects. There could be several reasons for this, including the relative distribution of mild, moderate and severe cases within the samples. Mild and moderate $\mathrm{OI}$ tends to be associated with collagen defects and more severe forms of the disease are associated with noncollagenous defects. ${ }^{46,55}$ This discrepancy may also be due to the superior proficiencies of next-generation sequencing as compared to Sanger sequencing which was predominantly used in previous studies. Finally, these findings could truly represent population differences in the molecular diversity of OI defects. These contradictions between previous literature and more recent studies indicate that the more we are learning about $\mathrm{OI}$, the more questions arise.

With the availability and reduction in the cost of next-generation sequencing, a "genotype first - phenotype later" approach may soon be the more desired approach implemented. The "genotype first- phenotype later" approach has limitations with regard to predicting clinical outcomes as genotype-phenotype correlations are still not well established in OI patients. Families with the same pathological variant have been shown to have heterogenous clinical features and conflicting findings are common between Ol studies. For example, a study of Swedish OI patients ${ }^{56}$ observed that those without collagen I mutations do not have dental aberrations, whereas a large study of Italian OI patients found that $33.3 \%$ of patients with these defects have dentinogenesis imperfecta. ${ }^{57}$ These are starkly contrasting findings. New genetic variants are constantly being found that do not relate to known pathogenic variants, but patients have similar phenotypes. A study on a Palestinian sample of only 77 Ol patients found 11 novel pathogenic variants in known disease-causing genes and $10 \%$ of their sample had no pathogenic variants in known disease-causing genes. ${ }^{58}$ Therefore, the more that is understood about genotype-phenotype correlations, the more it will become clinically useful and informative to the clinician, patients and genetic councilors. It would be advisable that equal emphasis is placed on both genotyping and phenotyping. The ever-evolving nosologies remain a useful reference for diagnosis and genetic counseling. However, the limitations of these reference guides need to be acknowledged.

In terms of the clinical classification of OI, information concerning newly discovered genes was initially merged into Sillence types I to IV, which reflected clinical severity. Type V, which was added, has distinct radiographic features in comparison to the other types. Difficulties arose with this classification in the provision of accurate genetic counseling as the condition may change in severity during the lifetime of an affected person. Thereafter, a functional classification system was proposed in which it was suggested that the subtype of OI should be classified based on the underlying pathological mechanism of disease. In this way, primary collagen structure and function, together with defects in ossification and mineralization would be grouped together. The genetic classification, which has now evolved has expanded upon the original Sillence classification and a new subtype has been proposed for each defective gene. The genome database,
OMIM, currently lists 20 types of OI, OI types I to XX. This numerical listing is an amalgamation of the original 5 clinical types with 15 further genotypes resulting from dominant, AR or sex-linked inheritance. It is anticipated that this classification will continually evolve as novel genes are discovered.

Despite the lack of current consensus as to how to incorporate the newly discovered genes for $\mathrm{OI}$ into a clinically useful system, there is no doubt that their identification has provided crucial information. In particular, these novel gene discoveries have expedited investigations into pathogenic pathways involved in $\mathrm{Ol}$ and this information concerning the molecular pathogenesis has resulted in the development of specific therapeutic medical interventions.

A regularly updated nosology is also easy to disseminate and enhances communication between stakeholders, which would otherwise need to navigate the barrage of the literature that is constantly produced on the topic. A web-based nosology with all relevant clinical and molecular information with links to relevant studies and data and allows for a variety of targeted searches, ${ }^{32}$ would complement the published nosology and overcome the limitations of the nosology falling behind between revisions. ${ }^{59,60}$ One such database is the Osteogenesis Imperfecta \& Ehlers Danlos syndrome Variant Database hosted by the University of Leicester (https://www.le.ac.uk/genetics/ collagen/).

\section{5 | CONCLUSION}

The understanding of $\mathrm{OI}$ has undergone rapid changes over the last decade and significant genetic concepts have been promulgated. The successive revisions of the nosology and classification of OI have highlighted the importance of the nomenclature of the condition in order for it to be recognized by clinicians, scientists and patient advocacy groups. In this way, improved counseling of patients and individualized, tailored therapeutic approaches based on the underlying pathophysiology of the individual's type of OI have been facilitated. However, the rate of new findings makes it impossible to remain abreast of new findings. Therefore, a web-based, constantly updated resource is desirable to complement the widely disseminated and accepted nosology.

\section{CONFLICT OF INTEREST}

The authors declare no potential conflict of interest.

\section{DATA AVAILABILITY STATEMENT \\ $\mathrm{N} / \mathrm{A}$}

\section{ORCID}

Manogari Chetty (iD) https://orcid.org/0000-0002-1176-8539

Imaan Amina Roomaney (D) https://orcid.org/0000-0001-6789-5484

\section{REFERENCES}

1. Rossi V, Lee B, Marom R. Osteogenesis imperfecta: advancements in genetics and treatment. Curr Opin Pediatr. 2019;31(6):708-713. 
2. Beighton P. McKusick's Heritable Disorders of Connective Tissue. 5th ed. St. Louis: Mosby; 1993:281-295.

3. Weil UH. Osteogenesis imperfecta: historical background. Clin Orthop Rel Res. 1981;159:6-10.

4. Sillence DO, Senn A, Danks DM. Genetic heterogeneity in osteogenesis imperfecta. J Med Genet. 1979;16:101-116.

5. Chetty M, Roberts T, Stephen LXG, Beighton P. Craniofacial manifestations in osteogenesis imperfecta type III in South Africa. BDJ Open. 2017;3:17021. https://doi.org/10.1038/bdjopen.2017.21.

6. Chetty M, Roberts T, Shaik S, Beighton P. Dentinogenesis imperfecta in osteogenesis imperfecta type $\mathrm{XI}$ in South Africa: a genotypephenotype correlation. BDJ Open. 2019;5(1):1-5.

7. Sillence DO, Rimoin DL. Classification of osteogenesis imperfecta. Lancet. 1978;311(8072):1041-1042.

8. Buttenberg $\mathrm{H}$, Rupprecht $\mathrm{E}$. Paris nomenclature of constitutional bone disease. Radiol Diagn. 1972;13(2):279-283.

9. Sillence DO. Osteogenesis imperfecta: an expanding panorama of variants. Clin Orthop Rel Res. 1981;159:11-25.

10. Sillence DO. Osteogenesis imperfecta nosology and genetics. Ann N Y Acad Sci. 1988;543:1-15.

11. Chu ML, Williams CJ, Pepe G, Hirsch JL, Prockop DJ, Ramirez F. Internal deletion in a collagen gene in a perinatal lethal form of osteogenesis imperfecta. Nature. 1983;304:78-80.

12. Beighton P, Giedion A, Gorlin R, et al. International classification of osteochrondrodysplasias. Am J Med Genet. 1992;44:223-229.

13. Hall C. International nosology and classification of constitutional disorders of bone (2001). Am J Med Genet. 2002;113:65-77.

14. Rauch F, Glorieux FH. Osteogenesis imperfecta. Lancet. 2004;363: 1377-1385.

15. Steiner, R.D., Pepin, M.G., Byers, P.H. 2005. Osteogenesis Imperfecta. GeneReviews NCBI Bookshelf ID: NBK1295PMID:20301472.

16. Warman ML, Cormier-Daire V, Hall C, et al. Nosology and classification of genetic skeletal disorders: 2010 revision. Am J Med Genet A. 2011;155(5):943-968.

17. Semler O, Garbes L, Keupp K, et al. A mutation in the $5^{\prime}-$ UTR of IFITM5 creates an in-frame start codon and causes autosomaldominant osteogenesis imperfecta type $\mathrm{V}$ with hyperplastic callus. Am J Hum Genet. 2012;91:349-357.

18. Pyott SM, Schwarze U, Christiansen HE, et al. Mutations in PPIB (cyclophilin B) delay type 1 procollagen chain association and result in perinatal lethal to moderate osteogenesis imperfecta phenotypes. Hum Mol Genet. 2011;20:1595-1609.

19. Cabral WA, Barnes AM, Adeyemo A, et al. A founder mutation in LEPRE1 carried by $1.5 \%$ of west Africans and $0.4 \%$ of African Americans causes lethal recessive osteogenesis imperfecta. Genet Med. 2012;14:543-551.

20. Martinez-Glez V, Valencia M, Caporros-Martin JA, et al. Identification of a mutation causing deficient BMP1/mTLD proteolytic activity in autosomal recessive osteogenesis imperfecta. Hum Mutat. 2012;33:343-350.

21. Caparros-Martin JA, Valencia M, Pulido V, et al. Clinical and molecular analysis in families with autosomal recessive osteogenesis imperfecta identifies mutations in five genes and suggests genotype-phenotype correlations. Am J Med Genet Part A. 2013;161A:1354-1369.

22. Eyre DR, Weis MA. Bone collagen: new clues to its mineralization mechanism from recessive osteogenesis imperfecta. Calif Tissue Int. 2013;93:338-347.

23. Volodarsky $\mathrm{M}$, Markus $\mathrm{B}$, Cohen I, et al. A deletion mutation in TMEM38B associated with autosomal recessive osteogenesis imperfecta. Hum Mutat. 2013;34:582-586.

24. Rubinato E, Morgan A, D'Eustacchio A, et al. A novel deletion mutation involving TMEM38B in a patient with autosomal recessive osteogenesis imperfecta. Gene. 2014;545(2):290-292.

25. Keupp K, Beleggia F, Kayserili H, et al. Mutations in WNT1 cause different forms of bone fragility. Am J Hum Genet. 2013;92:565-574. https://doi.org/10.1016/j.ajhg.2013.02.010.
26. Symoens S, Malfait F, Hondt S, et al. Deficiency for the ER-stress transducer OASIS causes severe recessive osteogenesis imperfecta in humans. Orphanet J Rare Dis. 2013;8:154.

27. Valadares ER, Carneiro TB, Santos PM, Oliveira AC, Zabel B. What is new in genetics and osteogenesis imperfecta classification? J Pediatr. 2014;90(6):536-541.

28. Forlino A, Cabral WA, Barnes AM, Marini JC. New perspectives on osteogenesis imperfecta. Nat Rev Endocrinol. 2011;7:540-557.

29. Van Dijk FS, Sillence DO. Osteogenesis imperfecta: clinical diagnosis, nomenclature and severity assessment. Am J Med Genet. 2014;164 (6):1470-1481.

30. Bonafe L, Cormier V, Hall C, et al. Nosology and classification of genetic skeletal disorders: 2015 revision. Am J Med Genet Part A. 2015;9999A:1-24.

31. Forlino A, Marini JC. Osteogenesis imperfecta. Lancet. 2016;387 (10028):1657-1671.

32. Mortier GR, Cohn DH, Cormier-Daire V, et al. Nosology and classification of genetic skeletal disorders: 2019 revision. Am J Med Genet A. 2019;179(12):2393-2419.

33. Superti-Furga A, Unger S. Nosology and classification of genetic skeletal disorders: 2006 revision. Am J Med Genet A. 2006;143A: 1-18.

34. Moosa S, Yamamoto GL, Garbes L, et al. Autosomal-recessive mutations in MESD cause osteogenesis imperfecta. Am J Hum Genet. 2019;105:836-843. https://doi.org/10.1016/j.ajhg.2019.08.008.

35. Mendoza-Londono R, Fahiminiya S, Majewski J, et al. Recessive osteogenesis imperfecta caused by missense mutations in SPARC. Am J Hum Genet. 2015;96:979-985.

36. Lindert U, Cabral WA, Ausavarat $\mathrm{S}$, et al. MBTPS2 mutations cause defective regulated intramembrane proteolysis in X-linked osteogenesis imperfecta. Nat Commun. 2017;7:11920.

37. Pekkinen M, Terhal PA, Botto LD, et al. Osteoporosis and skeletal dysplasia caused by pathogenic variants in SGMS2. JCI Insight. 2019; 4(7):e126180. https://doi.org/10.1172/jci.insight.126180.

38. Jin L, Liu Y, Sun F, et al. Three novel ANO5 missense mutations in Caucasian and Chinese families and sporadic cases with gnathodiaphyseal dysplasia. Sci Rep. 2017;7:40935. https://doi.org/ 10.1038/srep40935.

39. Van Hul B, Van Hul W. Mechanisms in endocrinology: genetics of human bone formation. Eur J Endocrinol. 2017;177(2):69-83.

40. Kaneto CM, Lima PSPC, Zanette DL, et al. COL1A1 and miR-29b show lower expression levels during osteoblast differentiation of bone marrow stromal cells from osteogenesis imperfecta patients. BMC Med Genet. 2014;15:45.

41. Laine CM, Joeng KS, Campeau PM, et al. WNT1 mutations in earlyonset osteoporosis and osteogenesis imperfecta. N Engl J Med. 2013; 368:1809-1816. https://doi.org/10.1056/NEJMoa1215458.

42. Hanagata N. FITM5 mutations and osteogenesis imperfecta. J Bone Miner Metab. 2016;34:123-131. https://doi.org/10.1007/s00774015-0667-1.

43. Hartikka H, Makitie O, Mannikko M, et al. Heterozygous mutations in the LDL receptor-related protein 5 (LRP5) gene are associated with primary osteoporosis in children. J Bone Miner Res. 2005;5(20):783789. https://doi.org/10.1359/JBMR.050101.

44. Wu M, Chen G, Li YP. TGF-beta and BMP signaling in osteoblast, skeletal development, and bone formation, homeostasis and disease. Bone Res. 2016;4:16009. https://doi.org/10.1038/boneres. 2016.9.

45. Laine CM, Wessman M, Toiviainen-Salo S, et al. A novel splice mutation in PLS3 causes X-linked early onset low-turnover osteoporosis. J Bone Miner Res. 2015;30:510-518. https://doi.org/10.1002/jbmr. 2355.

46. Fernandes AM, Rocha-Braz MGM, França MM, et al. The molecular landscape of osteogenesis imperfecta in a Brazilian tertiary service cohort. Osteoporos Int. 2020;1-12. 
47. Cho TJ, Lee KE, Lee SK. A single recurrent mutation in the 5'-UTR of IFITM5 causes osteogenesis imperfecta type V. Am J Hum Genet. 2012; 91:343-348.

48. Patel RM, Nagamani SC, Cuthbertson D, et al. A crosssectionalmulticenter study of osteogenesis imperfecta in North America - results from the linked clinical research centers. Clin Genet. 2015;87:133-140.

49. Hald JD, Folkestad L, Harsløf T, et al. Skeletal phenotypes in adult patients with osteogenesis imperfecta-correlations with COL1A1/COL1A2 genotype and collagen structure. Osteoporos Int. 2016; 27(11):3331-3341.

50. Marini JC, Forlino A, Bachinger HP, et al. Osteogenesis imperfecta. Nat Rev Dis Primers. 2017;3:17052.

51. Glorieux FH, Rauch F, Plotkin H, et al. Type $V$ osteogenesis imperfecta: a new form of brittle bone disease. J Bone Miner Res. 2000;15:1650-1658.

52. Liu $\mathrm{Y}$, Asan MD, et al. Gene mutation spectrum and genotypephenotype correlation in a cohort of Chinese osteogenesis imperfecta patients revealed by targeted next generation sequencing. Osteoporos Int. 2017;28:2985-2995.

53. MohdNawawi N, Selveindran NM, Rasat R, et al. Genotypephenotype correlation among Malaysian patients with osteogenesis imperfecta. Clin Chim Acta. 2018;484:141-147.

54. Mrosk J, Bhavani GS, Shah H, et al. Diagnostic strategies and genotype-phenotype correlation in a large Indian cohort of osteogenesisimperfecta. Bone. 2018;110:368-377.

55. Bardai G, Moffatt P, Glorieux FH. DNA sequence analysis in 598 individuals with a clinical diagnosis of osteogenesis imperfecta: diagnostic yield and mutation spectrum. Osteoporos Int. 2016;27:3607-3613.
56. Lindahl K, Astrom E, Rubin CJ, et al. Genetic epidemiology, prevalence, and genotype-phenotype correlations in the Swedish population with osteogenesis imperfecta. Eur J Hum Genet. 2015;23:10421050.

57. Maioli M, Gnoli M, Boarini M, et al. Genotype-phenotype correlation study in 364 osteogenesis imperfecta Italian patients. Eur J Hum Genet. 2019;27(7):1090-1100.

58. Essawi O, Symoens S, Fannana M, et al. Genetic analysis of osteogenesis imperfecta in the Palestinian population: molecular screening of 49 affected families. Mol Genet Genom Med. 2018;6(1):15-26.

59. Dalgleish R. The human type I collagen mutation database. Nucleic Acids Res. 1997;25:181-187.

60. Dalgleish R. The human collagen mutation database 1998. Nucleic Acids Res. 1998;26:253-255.

61. Kaneto CM, Lima PS, Zanette DL, Neto JM, de Paula FJ, Silva WA, et al. COL1A1 and miR-29b show lower expression levels during osteoblast differentiation of bone marrow stromal cells from Osteogenesis Imperfecta patients. BMC medical genetics. 2014;15 (1):1-5.

How to cite this article: Chetty M, Roomaney IA, Beighton P. The evolution of the nosology of osteogenesis imperfecta. Clinical Genetics. 2021;99:42-52. https://doi.org/10.1111/ cge.13846 